\title{
WOMEN'S STATUS AND WORLD-SYSTEM POSITION: AN EXPLORATORY ANALYSIS
}

\author{
Richard York \\ Department of Sociology \\ University of Oregon \\ rfyork@uoregon.edu \\ Christina Ergas \\ Department of Sociology \\ University of Oregon \\ cergas@uoregon.edu
}

\begin{abstract}
Our aim here is to strengthen the links between the world-systems perspective and research on gender inequality. Grounding our analysis in theories assessing the connections between gender relationships and world-system processes, we empirically explore (1) the extent to which women's status in nations overlaps with the world-system position of those nations and (2) the influence of women's status within nations on a variety of national characteristics. We find that women's status has a moderately strong association with world-system position, which suggests that macro-comparative research may confound the respective effects on a variety of social characteristics of women's status and world-system position if indicators of both factors are not included in analyses. We also find that, controlling for world-system position, GDP per capita, and urbanization, in nations where women have higher status (variously measured), total fertility rates, infant mortality rates, military expenditures, and inflows of foreign direct investment are lower, and public health care expenditures and per capita meat consumption are higher. These results suggest that women's status likely has social effects that can be seen on the macro-level, and that world-systems analysts should pay more attention to theories of gender in their research.
\end{abstract}

\section{INTRODUCTION}

A decade ago, Wilma Dunaway (2001: 2) observed that "women are only a faint ghost in the world-system perspective." She noted that very few articles in the two leading journals in the field, Review and the Journal of World-Systems Research, addressed gendered exploitation, women, or households. A quick perusal of the tables of content of issues of these journals published since Dunaway presented her assessment demonstrates that not much has changed over the first decade of this century (although, for a noteworthy exception, see the special issue of Review [Feldman 2007a] dedicated to an appreciation of the work of Joan Smith). Gender and women remain largely outside of the theoretical and research foci of the world-systems perspective. 
In some ways, this is not entirely surprising. The world-systems perspective is characterized by a macro-level focus, whereas gender and gendered processes are typically theorized at a micro-level. After all, nations do not have genders. However, gender influences macro-level processes in important ways, including the machinations of the world-system, and world-system processes influence the lives of women and men and gender relationships. Therefore, our theoretical understanding of world-systems can be enhanced by taking gender seriously. Micro-level gendered processes are clearly important to explore within the worldsystem, however, to advance our current argument, we focus on the macro-level.

Our aim here is to help strengthen the link between the world-systems perspective and research on gender inequalities and to demonstrate how both literatures can inform each other ${ }^{1}$. To do this, we give a brief overview of some of the theories of gender inequalities that address how world-system processes and other macro-level phenomena are gendered in various ways and how gendered work is affected by world-system processes. We then present several exploratory empirical analyses to show that (1) women's status is connected to the structure of the worldsystem and, therefore, macro-level analyses that ignore women's status may confound gendered effects with world-system position effects, and (2) women's status within nations adds explanative power above and beyond those of world-system position and indicators of "modernization" and "development" in quantitative models of a variety of factors that are of interest to world-systems theorists. Finally, we offer some suggestions for future avenues of research examining gendered processes in world-systems.

\section{THE GENDERED WORLD-SYSTEM}

Analyses in the world-systems tradition typically focus on macro-structural factors such as trade networks, foreign direct investment, national debt, and GDP (Hall 2000; Misra 2000). These analyses have shed considerable light on the processes that produce and reproduce global inequalities. However, although the macro-structural factors that are typically included in these analyses are important indicators of dependency and the relative global influence of nations, they can obscure the gendered character of organizations, hidden work in commodity chains, and unequal relations within nations (Buchmann 1996; Dunaway 2001). The actors implicit in the activities that underlie these macro-structural factors are typically men and male-dominated organizations, while the activities of women are neglected (Waring 1999; Acker 2006). Overlooking gender, therefore, can limit the scope and explanatory power of the world-systems approach, since doing so can cause analysts to miss a large part of the social world - i.e., the world as experienced by women, who make up more than half of the world's population. Incorporating gender into the world-systems perspective presents a challenge, since the perspective focuses on large-scale processes and the configuration of relationships among nations. By focusing on relations among nations, and critiquing more powerful, core nations, world-systems analyses frequently fail to acknowledge the contributions of women to the world

\footnotetext{
${ }^{1}$ Our goal is not to debate the utility of micro-gender versus macro-world-systems analyses, nor do we seek to promote one level of analysis over the other. However, for a detailed discussion of these issues see Fernandez-Kelly (1994) and Misra (2000).
} 
economy $^{2}$ (Buchmann 1996; Mies 1998). Here, we outline the contributions of gender scholars by reviewing some theoretical positions that help us understand the underlying gendered construction of the world-economy and the ways in which women are often made invisible in macro-structural analyses. We do this so as to expand the scope of the world-systems tradition and demonstrate the potential for macro-comparative empirical research to address questions about women's status and gender relationships.

Gender scholars have raised important concerns regarding the use of macro-levels of analysis. Coming from a critique of so-called "value neutral," male dominated epistemologies that objectify the subjects under study, gender research has a longstanding theoretical commitment to methodologies that take the individual as the unit of analysis (Merchant 1990; Naples 2003). Gender researchers have preferred methods that maintain women's status as subjects and explore problems that appear in their everyday worlds, such as household work distribution between women and men (Smith 1987; Harding 1991; Naples 2003). Gender scholars assert that research questions should be situated in the lived experiences of individuals in order to highlight oppressive relations and the contributions of invisible groups (Smith 1987; Misra 2000). Because of this, gender scholarship tends to focus on micro-processes, including gender relations and interactions.

Although the world-systems perspective takes the world-system as the unit of analysis and researchers tend to focus on macro-processes, gender and world-systems scholars do not necessarily have competing agendas (Fernandez-Kelly 1994; Hall 2000; Misra 2000). Both attempt to shed light on the relationship between general patterns and particular events with a critical eye towards power relations. The world-systems perspective lends itself to dialectical analysis of the relationship between local conditions or particular events and the global and historical contexts within which these events occur. Bunker's (1984) work on how the Brazilian Amazon became an extractive economy is an example of research that focuses on a local condition within the global economy. Hall (2000) addresses the "dual research agenda" of worldsystems analysis - how the processes of the system affect the social structures of its constituent parts, and how changes in the internal social structure affect the system. From this he notes "the dialectic between local and global implicit in the dual research agenda is the heart of worldsystems analysis" (p. 6). However, in practice world-systems analyses tend to look at the effect of global forces on local events, while gender analyses tend to look at how women and men contribute to and attempt to change structural processes.

Despite these general tendencies, some gender theorists do have a broader structural view of how the history of capitalist development is a gendered and racialized phenomenon. They argue that as practices around wages and labor markets bureaucratize, gender and racial inequalities are institutionalized (Nash 1988; Waring 1999; Acker 2006; Pellow 2007; Salleh 2009). Acker (2006: 9) asserts "a relatively small group of white men drove the development of capitalist production, reworking forms of male domination as intrinsic to emerging class relations, and organizing the new factories, and, later, the new offices based on the assumptions about the masculine individual as the normal human being." One example of how the workplace is

\footnotetext{
${ }^{2}$ We also recognize that the contributions of indigenous people are frequently neglected, and serious consideration of race/ethnicity and culture is often absent from most macro-level research. We do not address these issues here since to do so adequately would require extensive treatment, and our focus is on gender.
} 
organized around the "normalized" masculine worker embedded in a gendered distribution of labor is the expectation that an employee can work long or odd hours without obligations in the home. This structure is based on the assumption that women provide domestic labor, enabling male workers to be available to meet the demands of employers. As these intrinsically gendered and racialized organizational processes are spread throughout the world-system, male hegemony is reinforced in preexisting patriarchal cultures around the globe. One such example is the Iranian Muslim household where women were employed by carpet manufacturers producing goods for trade with the West after the Second World War. In the home, men controlled their wives' money and spent it in ways that perpetuated male control, including investing in boys' but not girls' education (Nash 1988). Moreover, male hegemony is imposed on peoples with limited or no previous gender hierarchy, as in the case of the Cherokee frontier, where, before colonial influence, the Cherokee recognized matrilineal rights and celebrated women's subsistence labor (Dunaway 2000).

Gender scholars have demonstrated that women's work in the world economy is undervalued and, frequently, invisible (Mies 1998; Horton and Lee 1999; Waring 1999; Dunaway 2001; Acker 2006; Dunaway and Macabuac 2007; Federici 2009; Salleh 2009; Waring 2009). Women who do paid work, in accordance with standard economic definitions, tend to earn the lowest wages and do the least valued, although not unimportant, jobs. This is especially true for women of color (Acker 2006). Remuneration for women's devalued work can be understood as a type of unequal exchange, where women provide labor that is essential to society, but for which they receive little compensation. In addition, household and care-giving work, usually done by women, is typically non-waged, and thus is not calculated in productive economic terms, rendering it invisible in national accounts (Waring 1999). Moreover, household labor serves as the base of and subsidizes production in the capitalist world-system. Unpaid labor allows production costs to remain low, which, in turn, keeps commodities cheap and corporate profits high (Mies 1998; Acker 2006; Dunaway and Macabuac 2007).

Many world-systems theorists and other macro-comparative researchers have perpetuated the invisibility of women's work by over-focusing on indicators that Buchmann (1996), Waring (1999), and others have critiqued for their neglect of household and subsistence labor, such as GDP. Additionally, when world-systems theorists have written about household labor, they tend to do so without referring to the individuals doing the labor, who are typically women (Dunaway 2001). Neglecting to discuss women's labor is a huge oversight when considering that women worldwide are estimated to perform two-thirds of the world's work (UNICEF 2004). In fact, the global trend toward the "feminization of labor," both unwaged and waged in both informal and formal economic sectors, is a well documented phenomenon (Mies 1998; Moghadam 1999; Waring 1999; Parreñas 2001; Benería 2003).

To incorporate gender into the world-systems perspective, Dunaway (2001) suggests that world-systems theorists look at three constructs for gender analysis, specifically, the household, semiproletarianization, and commodity chains. Dunaway (2001: 6-7) further theorizes that three

\footnotetext{
${ }^{3}$ Due to competition, the "feminization of labor" is theorized to occur because multinational corporations increasingly need cheaper and more docile labor, and, given that women have historically been disenfranchised, women are seen as the most easily manipulated workers. However, there are many examples of women workers organizing around the world to combat deteriorating work conditions (Moghadam 1999).
} 
structural forces affect the household: trends in the world economy, state machinery, and ethnicity/culture/subculture. While these forces affect households, households are also sites where people reproduce and resist these structures.

Semiproletarianization of the household occurs when corporations externalize costs of production by paying waged workers less than the amount needed to reproduce their household. This systemic and institutionalized form of sexism forces households to absorb these costs through women's reproductive and subsistence labor (Dunaway 2001; Dunaway and Macabuac 2007). Individuals in households adapt to corporate externalization of production costs by pooling resources in order to live, including wages, reproduction, subsistence food production, and informal work, such as craft production. In Dunaway and Macabuac's (2007) research on Philippine export aquaculture, they observed resource pooling in a small, previously subsistence fishing community. In particular, they note that when this community's economy transitioned from subsistence fishing to commercial export aquaculture, malnutrition and hunger increased in the community. As a result of the loss of food and social services, women adapted by working three to four more hours a day without pay to help their husbands do their jobs, and produced and sold crafts, livestock, and dried oysters or fish in informal markets.

Dunaway (2001) contends that nodes of commodity chains are the most promising sites for analyzing gendered work. Bunker (1984) makes a similar argument for focusing on nodes when he explores the extraction economy in the Brazilian Amazon. He observes that "however global exchange systems have become, commodities can emerge only from locally based extractive and productive systems," (or, in this case, reproductive) (Bunker 1984: 1019). Further, Bunker goes on to suggest that "models of global and regional systems must therefore be complementary and cannot be treated as opposing paradigms" (p. 1019). Dunaway and Bunker are not alone in their assessment of the limitations of focusing on global processes to the neglect of processes occurring within nations. Others have argued that the world-systems perspective would benefit from analyzing smaller scale processes in the context of the world-system (Misra 2000; Engel-Di Mauro 2008).

Another way to incorporate gender into the world-systems perspective, and what we aim to do here, is to utilize quantitative macro-comparative analysis. We do not seek to promote macro-level analyses above micro-level, but, rather, we do seek to convey how applying different methodologies can allow us to learn different things about the social world. McCall (2005) argues that gender research would benefit from including more structural analyses in research on inequality. Additionally, development researchers have made important contributions while using quantitative, cross-national analyses by considering different aspects of women's status within nations and their relationship with various development indicators. In particular, Buchmann (1996) examines the relationship between women's education and structural adjustment policy and finds that macroeconomic policies, such as structural adjustment in the Third World, can have negative effects on women's educational and occupational achievement. Hadden and London (1996) conclude that educating girls is the best investment that lessdeveloped countries can make. Further, Shen and Williamson $(1997,2001)$ show that higher women's status, measured by education relative to men and reproductive autonomy, within a nation is correlated with lower incidence of maternal and infant mortality, while indicators of economic growth, like multinational corporate investment, have detrimental effects on mortality.

In light of the above considerations, it appears clear that the status of women within nations is both affected by and can affect various world-system processes. The exact ways in 
which gender matters will of course be context specific, but it appears that there are some general patterns that we can expect to emerge. Below, we examine how women's status fits in the modern world-system and begin to explore what macro-structural factors it may affect.

\section{POTENTIAL CONFOUNDING OF WOMEN'S STATUS AND WORLD-SYSTEM POSITION}

There is a rich and growing body of quantitative empirical work showing the connections between position in the world-system and a wide variety of social and environmental conditions (e.g., Jorgenson 2003; McKinney, Kick, and Fulkerson 2010). There is also a small body of literature that establishes a connection between women's status and environmental politics using cross-national quantitative analyses (Norgaard and York 2005; Nugent and Shandra 2009; Shandra, Shandra, and London 2008). Cross-national studies demonstrate how women's status within nations is closely linked to important development indicators, including infant mortality, fertility rates, and maternal mortality (Shen and Williamson 1997, 2001; Buchmann 1996; Hadden and London 1996). However, these literatures have not extensively addressed the degree to which world-system position and women's status are confounded. As a first step in demonstrating that it is important to incorporate gender into the world-systems perspective, here we assess the extent to which women's status and world-system position are empirically associated.

We compare world-system position with five indicators of women's status using crossnational data to establish the degree to which these overlap. For measures of women's status, we use the indices developed by Nugent and Shandra (2009), which are derived from principal component analytic methods, covering four areas of women's status: education ${ }^{4}$, economic/labor ${ }^{5}$, politics ${ }^{6}$, and health ${ }^{7}$. These variables were standardized for the sample of nations used to develop them (which varied from 80 to 133 based on data availability), each with a mean of 0 and a standard deviation of 1 . We used these to develop a fifth measure, overall women's status, by averaging these four indicators in nations where all four are measured, averaging three where only three are measured, and averaged two where only two are measured. ${ }^{8}$ This approach makes it so that the overall measure of women's status has better coverage than any one of the original indicators alone $(\mathrm{N}=139)$. The values and ranks on these five variables for a selection of nations are presented in Table 1 .

\footnotetext{
${ }^{4}$ Based on the female to male ratio of average years in school, gender parity index for gross enrollment ratio (all levels except pre-primary), and the ratio of female to male adult (aged 15+) literacy rate.

${ }^{5}$ Based on the ratio of estimated female to male earned income, female professional and technical workers $(\%$ of total), and female labor force ( $\%$ of total labor force).

${ }^{6}$ Based on seats in parliament held by women (\% of total), number of years women have had the right to vote as of 2004, and women in ministerial government (\% of total).

${ }^{7}$ Based on maternal mortality rate (per 100,000 live births), females living with HIV/AIDS (\% of total living with HIV/AIDS), and female infant mortality (deaths per 1,000 live births).

${ }^{8}$ Although the justification for combining these four variables into a single index is principally on substantive grounds, it is also justifiable on statistical grounds. The scale reliability coefficient (Cronbach's alpha) for these four variables is .793 and the average Pearson's r value for inter-item correlations is .523 .
} 
Table 1. Women's Status in a Selection of Nations.

\begin{tabular}{|l|l|l|l|l|l|}
\hline $\begin{array}{l}\text { Nation (world- } \\
\text { system position } \\
\text { block) }\end{array}$ & $\begin{array}{l}\text { Education } \\
\text { (rank, N=94) }\end{array}$ & $\begin{array}{l}\text { Econ./Labor } \\
\text { (rank, N=80) }\end{array}$ & $\begin{array}{l}\text { Politics } \\
\text { (rank, } \\
\text { N=129) }\end{array}$ & $\begin{array}{l}\text { Health } \\
\text { (rank, } \\
\text { N=133) }\end{array}$ & $\begin{array}{l}\text { Overall } \\
\text { rank, } \\
\text { N=139) }\end{array}$ \\
\hline U.S.A. (1) & $.753(16)$ & $.785(21)$ & $.343(42)$ & $1.209(17)$ & $.772(27)$ \\
\hline Germany (1) & & $.179(35)$ & $2.033(7)$ & $1.472(10)$ & $1.228(7)$ \\
\hline Brazil (2) & & $.165(36)$ & $-.803(108)$ & $-.126(74)$ & $-.255(82)$ \\
\hline Spain (2) & $.433(37)$ & $-.441(56)$ & $1.067(16)$ & $1.695(7)$ & $.688(29)$ \\
\hline Sweden (2) & $1.365(2)$ & $1.361(8)$ & $2.859(1)$ & $1.833(3)$ & $1.854(1)$ \\
\hline China (3) & $-.164(67)$ & & $-.046(67)$ & $.378(47)$ & $.056(61)$ \\
\hline India (3) & $-1.380(84)$ & & $-.148(69)$ & $-.314(80)$ & $-.614(103)$ \\
\hline Japan (3) & $.068(62)$ & $-.371(51)$ & $-.569(90)$ & $1.037(25)$ & $.041(63)$ \\
\hline Russia (4) & $.811(11)$ & $1.562(4)$ & & $.777(34)$ & $1.050(12)$ \\
\hline Romania (4) & $.295(43)$ & $.687(25)$ & $.386(40)$ & & $.456(40)$ \\
\hline Vietnam (5) & $-.579(73)$ & & & $.112(68)$ & $-.234(80)$ \\
\hline Saudi Arabia (5) & $-.456(72)$ & $-2.369(80)$ & & & $-1.413(135)$ \\
\hline Ukraine (6) & $.292(44)$ & $1.264(9)$ & & $.598(39)$ & $.718(28)$ \\
\hline Kazakhstan (6) & $.325(40)$ & & $-1.067(116)$ & $-.431(85)$ & $-.391(92)$ \\
\hline Bangladesh (7) & & $-.789(63)$ & $-.783(106)$ & $-.048(72)$ & $-.540(99)$ \\
\hline Iran (7) & $-.680(75)$ & $-1.575(74)$ & $-1.133(119)$ & $.375(48)$ & $-.753(108)$ \\
\hline Nigeria (8) & & & $-.617(95)$ & $-1.254(116)$ & $-.936(116)$ \\
\hline Mexico (8) & $.392(39)$ & $-1.080(69)$ & $.025(58)$ & $.504(44)$ & $-.040(71)$ \\
\hline Ethiopia (9) & & & $-.203(71)$ & $-1.276(119)$ & $-.739(107)$ \\
\hline Sudan (9) & & & $-.965(113)$ & $-1.014(100)$ & $-.990(121)$ \\
\hline Laos (10) & $-1.493(86)$ & & $.084(56)$ & $-.637(90)$ & $-.682(106)$ \\
\hline Papua N.G. (10) & & & $-2.185(128)$ & $-.802(94)$ & $-1.493(136)$ \\
\hline Mongolia (10) & $1.621(1)$ & $.949(15)$ & $.143(54)$ & & $.904(15)$ \\
\hline
\end{tabular}

Note: The values for education, econ./abor, politics, and health are from Nugent and Shandra (2009) and are standardized scores, with a mean of 0 and a standard deviation of 1 . The overall measure is the mean of these scores (see text). The rank, with 1 indicating the nation with the highest women's status, is presented in parentheses. The block represents the world-system position block of each nation from Kick et al. (in press) - see Table 2.

We assessed the association between these five indicators of women's status and Kick, McKinney, McDonald, and Jorgenson's (in press) measure of world-system position. Their measure is for the period 1995-1999 and is essentially an updated version of the well-known measure developed by Snyder and Kick (1979). The measure was developed using multiplenetwork analysis of transnational economic, political, cultural, and military linkages among 160 nations. They assessed ties between nations across four relational dimensions - trading partners, co-membership in international non-governmental organizations, inter-nation embassy sponsorship, and arms transfers between nations. The multiple network analysis produced ten 
blocks of nations that are structurally situated in similar positions in the world-system. The ten blocks are summarized in Table 2.

Table 2. Summary of Kick et al.'s (in press) World-System Position (WSP) Measure and Women's Status.

\begin{tabular}{|l|l|l|}
\hline WSP block (N) & $\begin{array}{l}\text { Nations with largest } \\
\text { populations }\end{array}$ & $\begin{array}{l}\text { Overall women's status block } \\
\text { mean (rank) }\end{array}$ \\
\hline 1. Center Core (6) & $\begin{array}{l}\text { United States, Germany, } \\
\text { France, United Kingdom }\end{array}$ & $.819(1)$ \\
\hline 2. Western European (16) & $\begin{array}{l}\text { Brazil, Turkey, Spain, Poland, } \\
\text { Greece, Portugal }\end{array}$ & $.701(2)$ \\
\hline 3. Asian (12) & $\begin{array}{l}\text { China, India, Indonesia, } \\
\text { Pakistan, Japan }\end{array}$ & $-.029(5)$ \\
\hline 4. Eastern European (11) & $\begin{array}{l}\text { Russia, Romania, Czech } \\
\text { Republic, Hungary }\end{array}$ & $.555(4)$ \\
\hline $\begin{array}{l}\text { 5. Southeast Asian/Middle } \\
\text { East (6) }\end{array}$ & $\begin{array}{l}\text { Vietnam, Nepal, Saudi Arabia, } \\
\text { Cameroon }\end{array}$ & $-.629(9)$ \\
\hline 6. Former Soviet (14) & $\begin{array}{l}\text { Ukraine, Uzbekistan, } \\
\text { Kazakhstan, Belarus }\end{array}$ & $.597(3)$ \\
\hline 7. Middle East (9) & $\begin{array}{l}\text { Bangladesh, Egypt, Iran, } \\
\text { Morocco, Sri Lanka }\end{array}$ & $-.541(8)$ \\
\hline 8. South American (27) & $\begin{array}{l}\text { Nigeria, Mexico, Colombia, } \\
\text { Argentina, Kenya, Algeria }\end{array}$ & $-.098(6)$ \\
\hline 9. African (31) & $\begin{array}{l}\text { Ethiopia, Sudan, Uganda, } \\
\text { Ghana, Madagascar }\end{array}$ & $-.813(10)$ \\
\hline $\begin{array}{l}\text { 10. South Pacific/Middle East } \\
\text { (5) }\end{array}$ & $\begin{array}{l}\text { Laos, Papua New Guinea, } \\
\text { Eritrea, Mongolia, Fiji }\end{array}$ & $-.393(7)$ \\
\hline
\end{tabular}

Note: The number of nations in each block is presented in parentheses in the first column. Here we are considering only the nations for which there are data for the overall women's status variable, not all of the 160 nations included in Kick et al.'s (in press) analysis.

We regressed the five women's status indicators on the world-system position indicator, dummy-coded into the ten blocks. In Table 3 , we present $\mathrm{R}^{2}$ values from these analyses. Note that we do not present the full set of regression coefficients since we are focusing on the strength of association, which is the relevant issue with regards to assessing the extent to which these factors are confounded. However, a sense of the differences across blocks can be gained from the different mean values of the overall status of women by block presented in Table 2 . It is clear that there is a fairly strong association between world-system position and women's status, as indicated by the reasonably high $\mathrm{R}^{2}$ values. For example, world-system position explains more than half of the variance in overall women's status. We also regressed the five women's status variables on GDP per capita (purchasing power parity) for the year 2000 (World Bank 2007), and report the $\mathrm{R}^{2}$ values from these models in Table 3 . These associations are reasonably strong, 
although it is noteworthy that women's status is even more closely connected to world-system position than it is to GDP per capita, particularly for economic/labor status and educational status.

Table 3. Strength of Association $\left(\mathrm{R}^{2}\right)$ Between Indicators of Women's Status and Kick et al.'s (in press) World-System Position (WSP) Measure (ten blocks) and GDP per capita.

\begin{tabular}{|l|r|r|}
\hline & WSP R $^{2}$ & GDP p. c. R \\
\hline Overall status & .525 & .404 \\
\hline Educational status & .444 & .168 \\
\hline Economic/labor status & .432 & .060 \\
\hline Political status & .383 & .293 \\
\hline Health status & .709 & .600 \\
\hline
\end{tabular}

Note: All associations are significant at the .05 level. Results are derived from OLS regression. In the case of the WSP measure, the ten blocks were dummy-coded. Sample size varies across models.

Due to the reasonably strong associations between women's status and both worldsystem position and GDP per capita, statistical models using world-system position variables or GDP per capita as independent variables may suffer from confounding if they do not include indicators of women's status. Stated differently, some effects that may in truth stem from women's status may be erroneously attributed to economic factors or world-system position. These strong associations suggest that there are good reasons to consider including indicators of women's status in a substantial variety of quantitative macro-comparative analyses, since many dependent variables of interest to world-systems researchers may well be affected by gender relationships. Of course, women's status is affected by world-system position, and, therefore, to some degree the effects of women's status on other factors may indirectly reflect world-system effects.

However, clearly the status of women within a nation is not reducible to world-system position, and stems from multiple forces including local cultural traditions. In fact, even though the association between women's status and world-system position is fairly strong, clearly there is a substantial amount of variation in women's status across nations that is not explained by worldsystem position or modernization. As can be gleaned from Table 1, there is substantial variation in women's status within world-system blocks. For example, within block 2, Sweden has the highest level of overall women's status out of the 139 nations for which there are sufficient data, whereas Brazil is ranked $82^{\text {nd }}$. Similarly, within block 10 , Mongolia is the $10^{\text {th }}$ ranked on the overall status measure while Papua New Guinea is $136^{\text {th }}$. This indicates that world-system position and indicators of modernization cannot be used as proxies for measures of women's status. Therefore, it is clearly important to separate the effects of gender relationships from those 
of the factors that are typically directly included in world-system position indicators, such as the structure of trade networks and economic development.

\section{THE EXPLANATIVE POWER OF WOMEN'S STATUS IN MACRO-COMPARATIVE ANALYSES}

In addition to establishing that women's status and world-system position empirically overlap, for our basic underlying argument - that gender relationships have important macro-level effects that should not be ignored by world-systems researchers - to have force, it is necessary to demonstrate that women's status shows signs of having effects on a variety of features of societies above and beyond those of world-system position or modernization. To assess this issue, we examine six different features of nations that have been of interest to quantitative macro-comparative researchers: the total fertility rate, the infant mortality rate per 1000 births, government health expenditures as percentage of GDP, military expenditures as a percentage of GDP, net inflows of foreign direct investment as a percentage of GDP, and meat consumption per capita ( $\mathrm{kg} / \mathrm{year})$. With the exception of the meat variable, all of these variables are from the World Bank (2007) for the year 2004. The meat variable is from the World Resources Institute (2010) and is for the year 2002. ${ }^{9}$

These variables represent a diversity of social conditions. Total fertility rate and the infant mortality rate are indicators of reproductive health, spending on health care and the military get at social and political priorities, foreign direct investment deals with economic links to the global economy, and meat consumption is related to agricultural production processes and cultural characteristics (Buchman 1996; Benería 2003; Waring 1999; York and Gossard 2004). Thus, these variables were selected for analysis because they show some of the breadth of social features that gender relationships (along with world-system processes) may affect.

Using OLS regression, we assess the effects of women's status, controlling for important indicators of world-system position (WSP) and modernization, on the above mentioned variables. We use Kick et al.'s (in press) WSP measure, dummy-coded (using the "center core" block as the reference category). Using dummy codes is a more conservative approach than using the WSP measure as a continuous variable, since it does not require parametric assumptions about the measure (e.g., that it is measured at the interval level). Furthermore, although the order of the blocks represents a rough hierarchy, Kick et al. (in press) do not present their measure as a continuous variable. We also include GDP per capita (purchasing power parity) and urbanization (percentage of the population living in urban areas), both measured in the year 2000 (World Bank 2007), as indicators of development. For each model, we select the indicator of women's status

\footnotetext{
${ }^{9}$ This is the most recent year for which data are available. We are aware that since one of the variables used to produce the women's status indices is from 2003, there is a conceptual problem with using this index to predict the values of a variable from an earlier point in time (note: the fact that the number of years women have had the right to vote was measured as of 2004 is not an issue, since the relevant issue is when women gained the right to vote; therefore, the number of years since women gained the right to vote as of 2004 is perfectly correlated with the number of years since they gained the right to vote as of 2002). However, since (1) both meat consumption and women's status are almost surely highly stable over short periods of time and (2) we are conducting here an exploratory analysis, rather than trying to develop a definitive model, we do not consider this to be a substantial problem.
} 
that seems most theoretically appropriate for the dependent variable. For total fertility rate and infant mortality rate, we use women's educational status, since this is frequently identified as an important factor. ${ }^{10}$ For health and military expenditures, we use women's political status, since both these measures are of government funding and, therefore, stem from political decisions. We use women's overall status for the analyses of foreign direct investment and meat consumption, since these are likely affected by a broader range of social factors.

It is important to note that we do not present any of these models as definitive. Clearly, each one of the dependent variables we analyze is influenced by a variety of factors and more developed models would be required to fully examine them. We present our analyses as initial and exploratory with the aim of demonstrating the potential for women's status to add explanative power to a variety of models above and beyond what is given by measures of development and world-system position.

The results of our analyses are presented in Table $4 .{ }^{11}$ For all of the dependent variables, the women's status has an effect that is significant at least at the .05 level using a two-tailed test, with the exception of the model of health expenditures, where the women's status variable only has a significant effect at the .05 level using a one-tailed test (or at the .10 level using a two-tailed test). ${ }^{12}$ This is quite remarkable in light of the fact that the models control for major macrostructural features that are often largely seen as determining characteristics of nations.

\footnotetext{
${ }^{10}$ We do not use the women's health status variable to explain infant mortality because of its partially tautological nature. First, the health status variable includes female infant mortality, which is part of total infant mortality. Second, maternal mortality is part of the women's health status indicator, and maternal mortality is a common cause of infant mortality.

${ }^{11}$ Note that we have tested the robustness of these models. We re-estimated the models with Whitecorrected standard errors, which addresses potential heteroskedasticity. For all of these models the women's status variable had a significant effect at the .05 level with a two-tailed test, except for the infant mortality model, where the women's status variable only had a significant effect with a one-tailed test, and the FDI model, where women's status did not have a significant effect. We also estimated the models using the more traditional three-tier conceptualization of WSP, where, as per Kick et al.'s (in press) suggestion, blocks 1-3 were considered the core, blocks 4-8 the semiperiphery, and blocks 9-10 the periphery. In all of these models the women's status variable had an effect that was significant at the .05 level with a two-tailed test, except for in the FDI model. We also estimated the models using the 10-block WSP variable as a continuous variable, although dummy-coding each block, as we do in the models we present, is the more conservative approach that requires fewer assumptions about the nature of WSP and how it is measured. Kick et al. (in press) note that the order of blocks is approximately the order of network centrality in the global system. In these models, the women's status variable is significant at the .05 level with two-tailed tests for every dependent variable except FDI. We also checked for multicollinearity by calculating the variance inflation factor (VIF). The highest mean VIF for any model was only 3.84 and the highest VIF for any single coefficient was 8.24 ; values well within accepted standards. Taken together, these assessments suggest that the results we report here are reasonably robust. ${ }^{12}$ Note that in an alternative model of health expenditures using the educational status variable instead of the political status variable, women's status has a significant effect at the .05 level using a two-tailed test. However, we present the model using women's political status so as to be consistent with the logic we use to justify including political status in the military expenditures model, i.e., government expenditures are based on political decisions.
} 
Table 4. Total Fertility Rate (TFR), Infant Mortality Rate, Government Expenditures on Health Care, Military Expenditures, Net Inflows of Foreign Direct Investment (FDI), and Meat Consumption per capita Regressed on Women's Status (educational, political, or overall), GDP per capita, Urbanization, and World-System Position (ten blocks).

\begin{tabular}{|c|c|c|c|c|c|c|}
\hline & $\begin{array}{l}\text { TFR } \\
\text { Coef. } \\
\text { (S.E.) }\end{array}$ & $\begin{array}{l}\text { Infant } \\
\text { mortality } \\
\text { Coef. } \\
\text { (S.E.) }\end{array}$ & $\begin{array}{l}\text { Health } \\
\text { exp. } \\
\text { Coef. } \\
\text { (S.E.) }\end{array}$ & $\begin{array}{l}\text { Military } \\
\text { exp. } \\
\text { Coef. } \\
\text { (S.E.) }\end{array}$ & $\begin{array}{l}\text { FDI, net } \\
\text { inflows } \\
\text { Coef. } \\
\text { (S.E.) }\end{array}$ & $\begin{array}{l}\text { Meat per } \\
\text { capita } \\
\text { Coef. } \\
\text { (S.E.) }\end{array}$ \\
\hline Educational status & $\begin{array}{l}-.576 \\
(.138)^{* * *}\end{array}$ & $\begin{array}{l}-9.299 \\
(4.116)^{*}\end{array}$ & & & & \\
\hline Political status & & & $\begin{array}{l}.310 \\
(.166) \dagger\end{array}$ & $\begin{array}{l}-.426 \\
(.183)^{*}\end{array}$ & & \\
\hline Overall status & & & & & $\begin{array}{l}-7.499 \\
(3.698)^{*}\end{array}$ & $\begin{array}{l}8.101 \\
(3.221)^{*}\end{array}$ \\
\hline GDP per capita & $\begin{array}{l}.008 \\
(.014)\end{array}$ & $\begin{array}{l}.434 \\
(.232) \dagger\end{array}$ & $\begin{array}{l}.098 \\
(.025)^{* * * *}\end{array}$ & $\begin{array}{l}.031 \\
(.028) \\
\end{array}$ & $\begin{array}{l}1.684 \\
(.360)^{* * * *}\end{array}$ & $\begin{array}{l}1.889 \\
(.333)^{* * *}\end{array}$ \\
\hline Urbanization & $\begin{array}{l}-.009 \\
(.007)\end{array}$ & $\begin{array}{l}-166 \\
(.146) \\
\end{array}$ & $\begin{array}{l}.014 \\
(.008) \dagger\end{array}$ & $\begin{array}{l}.021 \\
(.010)^{*}\end{array}$ & $\begin{array}{l}-.095 \\
(.110) \\
\end{array}$ & $\begin{array}{l}.374 \\
(.100)^{* * *}\end{array}$ \\
\hline WSP 2 & $\begin{array}{l}-.142 \\
(.313)\end{array}$ & $\begin{array}{l}-1.150 \\
(3.984)\end{array}$ & $\begin{array}{l}-.354 \\
(.645)\end{array}$ & $\begin{array}{l}-.373 \\
(.681)\end{array}$ & $\begin{array}{l}19.864 \\
(9.386)^{*}\end{array}$ & $\begin{array}{l}3.555 \\
(8.732)\end{array}$ \\
\hline WSP 3 & $\begin{array}{l}-.318 \\
(.400)\end{array}$ & $\begin{array}{l}2.248 \\
(6.187)\end{array}$ & $\begin{array}{l}-1.508 \\
(.768) \dagger\end{array}$ & $\begin{array}{l}-1.171 \\
(.813)\end{array}$ & $\begin{array}{l}19.705 \\
(10.830) \dagger\end{array}$ & $\begin{array}{l}-4.994 \\
(10.381)\end{array}$ \\
\hline WSP 4 & $\begin{array}{l}-.371 \\
(.381)\end{array}$ & $\begin{array}{l}-6.438 \\
(5.273)\end{array}$ & $\begin{array}{l}.162 \\
(.787)\end{array}$ & $\begin{array}{l}-1.189 \\
(.833)\end{array}$ & $\begin{array}{l}29.477 \\
(11.427)^{*}\end{array}$ & $\begin{array}{l}18.442 \\
(10.424) \dagger\end{array}$ \\
\hline WSP 5 & $\begin{array}{l}1.879 \\
(.563)^{* *}\end{array}$ & & $\begin{array}{l}-3.088 \\
(.959)^{* *}\end{array}$ & $\begin{array}{l}.290 \\
(1.020)\end{array}$ & $\begin{array}{l}25.693 \\
(13.904) \dagger\end{array}$ & $\begin{array}{l}-2.333 \\
(11.812)\end{array}$ \\
\hline WSP 6 & $\begin{array}{l}-.068 \\
(.413)\end{array}$ & $\begin{array}{l}-1.923 \\
(7.392)\end{array}$ & $\begin{array}{l}-.868 \\
(.816)\end{array}$ & $\begin{array}{l}-1.511 \\
(.877)\end{array}$ & $\begin{array}{l}39.551 \\
(11.759) * *\end{array}$ & $\begin{array}{l}-4.720 \\
(10.897)\end{array}$ \\
\hline WSP 7 & $\begin{array}{l}-.320 \\
(.481)\end{array}$ & & $\begin{array}{l}-1.184 \\
(.921)\end{array}$ & $\begin{array}{l}.453 \\
(.958)\end{array}$ & $\begin{array}{l}26.703 \\
(12.171)^{*}\end{array}$ & $\begin{array}{l}2.287 \\
(11.379)\end{array}$ \\
\hline WSP 8 & $\begin{array}{l}.542 \\
(.478) \\
\end{array}$ & & $\begin{array}{l}-1.233 \\
(.773) \\
\end{array}$ & $\begin{array}{l}-1.839 \\
(.846)^{*}\end{array}$ & $\begin{array}{l}30.781 \\
(11.098)^{* *}\end{array}$ & $\begin{array}{l}6.894 \\
(10.278) \\
\end{array}$ \\
\hline WSP 9 & $\begin{array}{l}1.805 \\
(.518)^{* *}\end{array}$ & $\begin{array}{l}-11.328 \\
(8.946) \\
\end{array}$ & $\begin{array}{l}-.770 \\
(.795)\end{array}$ & $\begin{array}{l}-.593 \\
(.856) \\
\end{array}$ & $\begin{array}{l}28.863 \\
(11.521)^{*}\end{array}$ & $\begin{array}{l}.034 \\
(10.812)\end{array}$ \\
\hline WSP 10 & & & $\begin{array}{l}-1.021 \\
(.965)\end{array}$ & $\begin{array}{l}-1.940 \\
(1.145) \dagger\end{array}$ & $\begin{array}{l}30.168 \\
(13.884)^{*}\end{array}$ & $\begin{array}{l}37.826 \\
(13.503)^{* * *}\end{array}$ \\
\hline$y$-intercept & $\begin{array}{l}2.549 \\
(.509)^{* * * *}\end{array}$ & $\begin{array}{l}35.198 \\
(9.706)^{* *}\end{array}$ & $\begin{array}{l}3.017 \\
(.827)^{* * * *}\end{array}$ & $\begin{array}{l}2.014 \\
(.893)^{*}\end{array}$ & $\begin{array}{l}-31.973 \\
(12.113)^{* *}\end{array}$ & $\begin{array}{l}6.658 \\
(11.083) \\
\end{array}$ \\
\hline $\mathrm{N}$ & 62 & 29 & 117 & 101 & 130 & 131 \\
\hline $\mathrm{R}^{2}$ & .818 & .687 & .653 & .328 & .202 & .765 \\
\hline
\end{tabular}

Notes: Block 1, the "center core," is the omitted category for the WSP dummy-coded variables; $* * * p<.001, * * p<.01, * p<.05,+p<.10$ (two-tailed tests) 
Based on these results, we can say that there is clear evidence that where women have higher educational status, fertility rates and infant mortality rates are lower. These findings point to the major demographic and health consequences of women's status. Our results also suggest that women's status has a distinct effect on social priorities. Where women's status is higher, military expenditures are lower and government health care expenditures are higher. Our results also show that women's status is associated with national links to the global economy. There is less foreign direct investment in nations where women have higher status, which suggests that gender equality leads nations to be less dependent on the global economy. Finally, diet and agriculture also appear to be affected by women's status. Where women's status is higher, meat consumption is higher. Clearly, women's status is connected to a wide variety of processes and social outcomes.

These findings can be understood by reflecting back on some of theoretical issues we introduced above. Waring (1999) describes how social priorities are articulated in the global economic system through valuation. Specifically, she uncovers the "patriarchal nature of economics" and argues that "those who are making the decisions are men, and those values which are excluded from this determination are those of our environment, and of women and children" (p. 3). One example she explores is how military work is imputed into national economic figures and is considered active work and is paid labor, while reproductive work, of the household and human life, is considered inactive and goes unremunerated and unacknowledged. While Waring does not seek women's actual remuneration, she argues that without an imputation to account for unpaid labor, women's needs and contributions go unrecognized by policy-makers. Perhaps as a product of differentiated historical, material and social conditions, in particular, women's roles as primary caregivers and nurturers of households, and men's responsibilities to work outside the household to obtain money, women in positions of power tend to value different things than do men. For example, according to attitudinal research, women tend to express more concern for the environment than do men (Bord and O'Connor 1997; Davidson and Freudenburg 1996). These differences in valuation may explain many of our results, particularly the differences in military and health care spending across nations with respect to the status of women.

Reflecting on the effects of women's status on diet as well as infant mortality, it is worth noting that women and girls in Third World nations disproportionately experience malnutrition as compared to men and boys (Adams 1993; Dunaway 2001; Dunaway and Macabuac 2007). When food is scarce, mothers eat less food in order to feed their children and husbands. Additionally, male children are routinely fed better than girls (Adams 1993; Dunaway 2001; Dunaway and Macabuac 2007). In many societies, meat consumption is a cultural sign of status, and meat is often difficult to come by. For this reason, it is often reserved for men who are of higher status in the sex-hierarchy (Adams 1993).

\section{DIRECTIONS FOR ANALYSES OF GENDER IN THE WORLD-SYSTEM}

Our aim here has been to develop a link between theories of gender and the world-systems perspective, in particular to show that many aspects of the world-system are gendered, although these aspects have typically been neglected by world-systems researchers. We pointed to some of the existing theoretical work that examines both how gender relationships and women's status and actions affect many large-scale global processes and how global processes affect gender 
relationships, women, and the household within nations. We then demonstrated the potential importance of women's status in world-systems research by empirically assessing two issues. First, we demonstrated that there is a fairly strong association between world-system position and women's status within nations. This finding points to the potential for confounding in any empirical models that use world-system position indicators but that do not take into consideration women's status - i.e., results showing that world-system position affects any particular dependent variable may be spurious, or partially so, if the effects of women's status are neglected. Second, we presented exploratory models of six different dependent variables of interest in world-systems research: total fertility rate, infant mortality rate, public spending on health care, military expenditures, foreign direct investment, and meat consumption. For all six of these variables, we found that women's status had an effect above and beyond those of world-system position and indicators of "modernization." These results suggest that the neglect of gender relationships in empirical research is a major oversight, and that the inclusion of indicators of women's status has substantial potential to add explanative power to analyses of a wide variety of social conditions. Based on what we have presented here, we believe it is reasonable to conclude that, rather than asking whether or not to consider gender in world-systems research, important questions for scholars in the world-systems tradition include in what ways gender relationships affect the global economy, political structure, and cultural relations, and in what ways are gender relationships affected by the machinations of world-system processes.

We suggest that world-systems research should engage in efforts to both develop the theoretical connections between gender and the world-system and to develop empirical measures of gendered aspects of societies so that these factors can be included in macro-comparative models. Further engagement with theories of gender may provide new or more nuanced answers to old questions addressed in the world-systems literature and raise new questions and, therefore, novel avenues for research. One of the powers of engaging a diversity of theories is the potential to see the world in a variety of ways and, thereby, make discoveries that have been overlooked. The utilization of theories of gender may be one avenue for adding further vitality to the worldsystems tradition.

However, theoretical development alone will not be sufficient to bring considerations of gender into the world-systems tradition. One of the strengths of the world-systems tradition is its substantial body of empirical research, including a rich and growing quantitative macrocomparative literature. Incorporating gender into this literature will require the utilization of overlooked data sources and the gathering of data on a variety of social features that have not typically been central to analyses of world-system processes. An important source of data that is emerging is that developed by the WomenStats project (Caprioli et al. 2009), which provides the most comprehensive compilation of data, both qualitative and quantitative, on women's status currently available (http://www.womanstats.org/). The United Nations Development Program (UNDP) (2009) also tracks data on gender equality. The Gender-related Development Index, which is related to the widely used Human Development Index, is based on differences between men and women in life expectancy, literacy, education, and income. The UNDP (2009) has also developed the "gender empowerment measure," which is based on women's representation in government and professional occupations. In addition to measures of women's status, measures that assess the activities of women that are typically overlooked by traditional economic measures (e.g., GDP) would be highly useful. The Genuine Progress Indicator (GPI), an alternative to GDP, developed by Redefining Progress, represents an important move in this direction, in that it 
includes measures of the value of household labor and parenting as well as volunteer work (Talberth, Cobb, and Slattery 2007). However, the GPI has, to date, only been developed for the United States. If relevant data for measures like this were collected for all nations in the world, women's labor could be better represented in analyses.

Recognizing how gender relationships and women's status fit into the world-system is clearly a worthy, if challenging, task for scholars. Nonetheless, addressing gender can add theoretical depth to the world-systems tradition as well as enrich empirical research. Although gender has remained, at best, on the fringes of the world-systems perspective in the decade since Dunaway (2001) noted how women have been left out of this research tradition, perhaps the coming decade will see the development of enduring links between theories of gender and the world-systems perspective, thereby improving our understanding of our world.

\section{REFERENCES}

Acker, Joan. 2006. Class Questions: Feminist Answers. Lanham, MD: Rowman and Littlefield Publishers Inc.

Acosta-Belen, Edna and Christine E. Bose. 1990. "From Structural Subordination to Empowerment: Women and Development in Third World Contexts." Gender and Society. 4(3): 299-320.

Adams, Carol J. 1993. The Sexual Politics of Meat: A Feminist-Vegetarian Critical Theory. New York: The Continuum Publishing Company.

Benería, Lourdes. 2003. Gender, Development, and Globalization: Economics as if All People Mattered. New York: Routledge.

Bord, Richard J. and Robert E. O'Connor. 1997. "The Gender Gap in Environmental Attitudes: The Case of Perceived Vulnerability to Risk." Social Science Quarterly 78: 803-40.

Buchmann, Claudia. 1996. "The Debt Crisis, Structural Adjustment and Women's Education: Implications for Status and Social Development." International Journal of Comparative Sociology. 37: 5-30.

Bunker, Stephen G. 1984. "Modes of Extraction, Unequal Exchange, and the Progressive Underdevelopment of an Extreme Periphery: The Brazilian Amazon, 1600-1980." American Journal of Sociology 89(5): 1017-1064.

Caprioli, Mary, Valerie M. Hudson, Rose McDermott, Bonnie Ballif-Spanvill, Chad F. Emmett, and S. Matthew Stearmer. 2009. "The WomanStats Project Database: Advancing and Empirical Research Agenda." Journal of Peace Research 46(6): 839-851.

Collins, Jane L. 2007. "The Paradox of Poverty in the Transition from Welfare to Work." Review XXX(4): 283-311.

Davidson, Debra and William Freudenburg. 1996. "Gender and Environmental Risk Concern: A Review and Analysis of Available Research." Environment and Behavior 28:302-39.

Dickinson, Torry D. 2007. "(Hetero)Sexism as a Weapon of the World-System: Feminist Reflections on Household Research by Joan Smith and the Fernand Braudel Center." Review XXX(4): 261-281.

Dunaway, Wilma A. 2000. "Women at Risk: Capitalist Incorporation and Community Transformation on the Cherokee Frontier." Pp. 195-210 in A World-Systems Reader: New 
Perspectives on Gender, Urbanism, Cultures, Indigenous Peoples, and Ecology. Edited by Thomas D. Hall. Lanham, MD: Rowman and Littlefield Publishers.

. 2001. "The Double Register of History: Situating the Forgotten Woman and Her Household in Capitalist Commodity Chains." Journal of World-Systems Research VII(1): 2-29.

Dunaway, Wilma A. and M. Cecilia Macabuac. 2007. "The Shrimp Eat Better Than We Do": Philippine Subsistence Fishing Households Sacrificed for the Global Food Chain." Review XXX(4): 313-337.

Engel-Di Mauro, Salvatore. 2008. "Seeing the Local in the Global: Political Ecologies, WorldSystems, and the Question of Scale." Geoforum 40:116-125.

Federici, Silvia. 2009. "The Devaluation of Women's Labour." Pp. 43-65 in Eco-Sufficiency and Global Justice: Women Write Political Ecology, edited by Ariel Salleh. New York: Pluto Press.

Feldman, Shelley. 2007a. "Introduction." Review XXX(4): 237-242. . 2007b. "Households, Labor, and Global Capitalism: A Close Encounter with Joan Smith." Review XXX(4): 243-260.

Fernandez-Kelly, Patricia M. 1994. "Broadening the Scope: Gender and the Study of International Development." Pp. 143-168 in Comparative National Development. Edited by Douglas Kincaid and Alejandro Portes. Chapel Hill: University of North Carolina Press.

Hadden, Kenneth and Bruce London. 1996. "Educating Girls in the Third World: The Demographic, Basic Needs, and Economic Benefit." International Journal of Comparative Sociology. 37: 31-46.

Hall, Thomas D. 2000. "World-Systems Analysis: A Small Sample from a Large Universe." Pp. 3-27 in A World-Systems Reader: New Perspectives on Gender, Urbanism, Cultures, Indigenous Peoples, and Ecology. Edited by Thomas D. Hall. Lanham, MD: Rowman and Littlefield Publishers.

Harding, Sandra. 1991. Whose Science? Whose Knowledge?: Thinking from Women's Lives. Ithaca, NY: Cornell University Press.

Horton, John and Eun-Jin Lee. 1988. "Degraded Work and Devalued Labor: The Proletarianization of Women in the Semiconductor Industry." Pp. 137-152 in Racism Sexism, and the World-System, edited by Joan Smith, Jane Collins, Terence Hopkins, and Akbar Muhammad. New York: Greenwood Press.

Jorgenson, Andrew K. 2003. "Consumption and Environmental Degradation: A Cross-National Analysis of the Ecological Footprint." Social Problems 50: 374-394.

Kentor, Jeffrey. 2000. Capital and Coercion: The Economic and Military Processes that Have Shaped the World Economy 1800-1990. New York: Garland Publishing.

Kick, Edward L., Laura A. McKinney, Steve McDonald, and Andrew Jorgenson. (In press). "World-System Position: A Network Analysis of Nations." In Sage Handbook of Social Network Analysis, edited by John Scott and Peter Carrington. Thousand Oaks, CA: Sage Publications.

McCall, Leslie. 2005. "The Complexity of Intersectionality." Signs: Journal of Women in Culture and Society. 30(3): 1771-1800. 
McKinney, Laura A., Edward L. Kick, and Gregory M. Fulkerson. 2010. "World System, Anthropogenic, and Ecological Threats to Bird and Mammal Species: A Structural Equation Analysis of Biodiversity Loss." Organization \& Environment 23(1): 3-31.

Merchant, Carolyn. 1990. The Death of Nature: Women, Ecology and the Scientific Revolution. New York: Harper One.

Mies, Maria. 1998. Patriarchy and Accumulation on a World Scale: Women in the International Division of Labor." New York: Zed Books Ltd.

Misra, Joya. 2000. "Gender and the World-System: Engaging the Feminist Literature on Development." Pp. 105-127 in A World-Systems Reader: New Perspectives on Gender, Urbanism, Cultures, Indigenous Peoples, and Ecology. Edited by Thomas D. Hall. Lanham, MD: Rowman and Littlefield Publishers.

Moghadam, Valentine. 1999. "Gender and Globalization: Female Labor and Women's Mobilization." Journal of World-Systems Research. 5(2): 367-388.

Naples, Nancy. 2003. Feminism and Method: Ethnography, Discourse Analysis, and Activist Research. New York: Routledge.

Nash, June. 1988. "Cultural Parameters of Sexism and Racism in the International Division of Labor." Pp. 11-38 in Racism Sexism, and the World-System, edited by Joan Smith, Jane Collins, Terence Hopkins, and Akbar Muhammad. New York: Greenwood Press.

Norgaard, Kari and Richard York. 2005. "Gender Equality and State Environmentalism." Gender \& Society 19(4): 506-522.

Nugent, Colleen and John M. Shandra. 2009. "State Environmental Protection Efforts, Women's Status, and World Polity." Organization \& Environment 22(2): 208-229.

Parreñas, Rhacel Salazar. 2001. Servants of Globalization: Women, Migration and Domestic Work. Stanford, CA: Stanford University Press.

Rocheleau, Dianne, Barbara Thomas-Slayter, and Esther Wangari. 1996. "Gender and Environment: A Feminist Political Ecology Perspective." Pp. 3-26 in Feminist Political Ecology: Global Issues and Local Experiences, edited by Dianne Rocheleau, Barbara Thomas-Slayter, and Esther Wangari. New York: Routledge.

Roberts, J. Timmons, Bradley C. Parks, and Alexis A. Vásquez. 2004. "Who Ratifies Environmental Treaties and Why? Institutionalism, Structuralism and Participation by 192 Nations in 22 Treaties." Global Environmental Politics 4(3): 22-64.

Salleh, Ariel. 2009. "Ecological Debt: Embodied Debt." Pp. 1-41 in Eco-Sufficiency and Global Justice: Women Write Political Ecology, edited by Ariel Salleh. New York: Pluto Press.

Shandra, John M., Carrie L. Shandra, and Bruce London. 2008. "Women, Non-Governmental Organizations, and Deforestation: A Cross-National Study." Population \& Environment 30: 48-72.

Shen Ce and John B. Williamson. 1997. "Child Mortality, Women's Status, Economic Dependency, and State Strength: A Cross-National Study of Less Developed Countries." Social Forces. 76(2): 667-700.

. 2001. "Accounting for Cross-National Differences in Infant Mortality Decline (19651991) Among Less Developed Countries: Effects of Women's Status, Economic Dependency, and State Strength." Social Indicators Research. 53: 257-288.

Smith, Dorothy E. 1987. The Everyday World is Problematic. Boston, MA: Northeastern University Press. 
Smith, Joan. 1993. "We Irish Women: Gender, History, and the World-Economy." Review XVI(1): 1-15.

Snyder, David, and Edward L. Kick. 1979. "Structural Position in the World System and Economic Growth, 1955-1970: A Multiple-Network analysis of Transnational Interactions." American Journal of Sociology 84(5): 1096-1126.

Talberth, John, Clifford Cobb, and Noah Slattery. 2007. The Genuine Progress Indicator 2006: A Tool for Sustainable Development. Oakland, CA: Redefining Progress.

United Nations Children's Fund (UNICEF). 2004. "Gender Equality: The Big Picture." http:/www.unicef.org/gender/index bigpicture.html. Accessed July 6, 2010.

United Nations Development Program. 2009. Human Development Report 2009. New York: UNDP.

Waring, Marilyn. 1999. Counting for Nothing: What Men Value and What Women Are Worth ( $2^{\text {nd }}$ edition). Toronto: University of Toronto Press.

. 2009. "Policy and the Measure of Woman." Pp. 165-179 in Eco-Sufficiency and Global Justice: Women Write Political Ecology, edited by Ariel Salleh. New York: Pluto Press.

World Bank. 2007. World Development Indicators 2007. CD-ROM. Washington, D.C.: World Bank.

World Resources Institute. 2010. EarthTrends Searchable Database. (http:/earthtrends.wri.org). Accessed January 5, 2010.

York, Richard and Marcia Hill Gossard. 2004. "Cross-National Meat and Fish Consumption: Exploring the Effects of Modernization and Ecological Context." Ecological Economics 48(3): 293-302. 